\title{
Methodology of Experimental Analysis of Long-term Monitoring of Sandwich Composite Structure by Fibre-optic Strain Gauges
}

Dita Jiroutova

Klokner Institute, Czech Technical University in Prague. Solinova 7, 16608 Prague 6. Czech Republic. E-mail: Dita.Jiroutova@klok.cvut.cz

The aim of this article is proposition of new methodology of experimental analysis of long-term monitoring of sandwich composite structures. The sandwich composite structures are, due to its properties like stiffness, high impact strength, corrosion resistance, low thermal conductivity and low acoustic conductivity and, commonly used in civil engineering in recent years. This type of structure is composed of two main parts (face sheet and core) having different material and mechanical properties. Sudden change of these properties causes interlaminar stress in structure. A good knowledge about behaviour of sandwich composite structure is important for efficient manufacture techniques, long-term prediction of structure behaviour and for economics. The experimental part has been focused on obtaining the experimental results of deformation between layers of sandwich composite structure during long-term monitoring. The long-gauge optical fibres SOFO ${ }^{\circledR}$ SMARTape Compact have been used for longterm monitoring of sandwich composite structures. Long-gauge optical fibres were placed between the foam core and an outer layer of the composite structure during manufacturing. Test specimens were loaded in three-point bending test.

Keywords: Deformation, Sandwich composite structure, Long-term monitoring, Fibre-optic strain gauge, Three-point bending test

\section{Acknowledgement}

This work has been supported by a research project of the Grant Agency of Czech Republic No. 14-35225P.

\section{References}

[1] STEEVES, C. A., FLECK, N. A. (2004). Collapse Mechanism of Sandwich Beams with Composite Faces and a Foam Core, Loaded in Three-point Bending. Part II: Experimental Investigation and Numerical Modelling. In: International Journal of Mechanical Sciences. Vol. 46, No. 4, pp. 585 - 608. Pergamon - Elsevier Science, Oxford, UK.

[2] DANIEL, I. M., ABOT, J. L. (1999). Fabrication, Testing and Analysis of Composite Sandwich Beams. In: Composites Science and Technology. Vol. 60, No. 12 - 13, pp. 2455 - 2463. Elsevier Science Ltd., Oxford, UK.

[3] GDOUTOS, E. E., DANIEL, I. M., WANG, K. A., ABOT, J. L. (2001). Nonlinear Behavior of Composite Sandwich Beams in Three-point Bending. In: Experimental Mechanics. Vol. 41, No. 2, pp. 182 - 189. Springer, New York.

[4] THOMSEN, O. T., FROSTIG, Y. (1997). Localized Bending Effects in Sandwich Panels. Photoelastic Investigation versus High-order Sandwich Theory Results. In: Composite Structures. Vol. 37, No. 1, pp. 97 - 108 . Elsevier Science Ltd., Oxford, UK.

[5] WEN, M., LUO, J. (2015). Study on Mechanical Properties of the Composite Resin Matrix Fiber Reinforced. In: Manufacturing Technology. Vol. 15, No. 2, pp. 243 - 249. Faculty of Production Technology and Management, Czech Republic.

[6] MIKAMI, T., NISHIZAWA, T. (2015). Health Monitoring of High-rise Building with Fiber Optic Sensor (SOFO). In: International Journal of High-Rise Buildings. Vol. 4, No. 1, pp. 27 - 37. CTBUH. Korea.

[7] KAWANO, Y., MIKAMI, T., KATSUKI, F. (2010). Health Monitoring of a Railway Bridge by Fiber Optic Sensor (SOFO). In: Proceedings of the Fifth European Workshop "Structural Health Monitoring 2010”, Naples, Italy (F. Casciati, M. Giordano (Ed.)), pp. 1319 - 1324. DEStech Publications, Inc., Pennsylvania, USA.

[8] GLISIC, B., BADOUX, M., JACCOUD, J.-P., INAUDI, D. (2000). Monitoring a Subterranean Structure with the SOFO System. In: Tunnel Management International Magazine. Vol. 2, No. 8, pp. 22 - 27. ITC Ltd., West Bengal.

[9] SHEFCHIK, B., TOMES, R., BELLI, R. (2011). Salt Cavern Monitoring System for Early Warning of Sinkhole Formation. In: Geotechnical Instrumentation News, December 2011. pp. 30 - 33. BiTech Publishers, Ltd. Canada.

[10] INAUDI, D., BELLI, R., GASPARONI, F., BRUNI, F., PARENTE, A., ZECCHIN, M. (2013). Detection and Localization of Micro Leakages in Multiphase Pipelines Using Distributed Fiber Optic Sensing. In: Rio Pipeline Conference \& Exhibition 2013. 11 p. Brasil. 
[11] De BONT, R., INAUDI, D. (2013). Fast Detection and Localization of Small Ammonia Leaks Using Distributed Fiber Optic Sensors. In: AIChE Technical Manual, Vol. 51, pp. 91 - 99. AIChE, New York.

[12] INAUDI, D. (2000). Development of a Displacement Sensor for the CERN-LHC Superconducting Cryo-dipoles. In: $14^{\text {th }}$ International Coference on Optical Fiber Sensors, Venice, Italy, 4 p. Italy.

[13] MARTINEK, R. (2004). Senzory v průmyslové praxi. 2004, 200 p. BEN - technická literature, Prague.

[14] GLIŠIC, B., INAUDI, D. (2007). Fibre Optic Methods for Structural Health Monitoring. 2007, 262 p. John Wiley \& Sons Ltd., London.

[15] EN ISO 527-4: Plastics - Determination of tensile properties - Part 4: Test conditions for isotropic and orthotropic fibre-reinforced plastic composites. Czech Standard. 1998, 20 p. Český normalizační institut, Prague.

[16] www.diabgroup.com

[17] www.esands.com - Data sheet of SOFO ${ }^{\circledR}$ SMARTape Deformation sensor.

Copyright @ 2016 . Published by Manufacturing Technology. All rights reserved. 